\title{
KEPUASAN HIDUP: TINJAUAN DARI KONDISI KEUANGAN DAN GAYA PENGGUNAAN UANG
}

\author{
Rosatyani Puspita Adiati ${ }^{\left.{ }^{*}\right)}$ \\ ${ }^{1}$ Departemen Psikologi, Fakultas Psikologi Universitas Airlangga, Surabaya 60286, Indonesia
}

"E-mail: rosatyani.adiati@psikologi.unair.ac.id

\begin{abstract}
Abstrak
Kepuasan hidup masyarakat Indonesia pada saat ini sangat dipengaruhi oleh faktor pendapatan dan kondisi keuangannya. Penelitian ini bertujuan untuk menganalisis pengaruh jumlah pendapatan, pengeluaran, tabungan, dan gaya penggunaan uang terhadap kepuasan hidup. Penelitian ini menggunakan pendekatan kuantitatif dan melibatkan 831 responden yang dipilih menggunakan teknik convenient sampling. Analisis data dilakukan dengan software $G^{*}$ Power untuk melihat effect size dan menggunakan teknik analisis regresi linear berganda dengan menggunakan software JASP versi 0.8.6. Hasil analisis data menunjukkan bahwa jumlah pendapatan, jumlah pengeluaran konsumtif, dan jumlah aset memiliki pengaruh yang signifikan terhadap kepuasan hidup. Gaya penggunaan uang dengan hemat dan berhati-hati memiliki pengaruh yang signifikan terhadap kepuasan hidup, sementara gaya menghabiskan uang dan menggunakan uang secara sia-sia tidak memiiki pengaruh signifikan terhadap kepuasan hidup. Penelitian ini membuktikan bahwa penggunaan uang secara terkontrol, baik untuk kebutuhan konsumtif maupun menabung untuk kebutuhan di masa depan, dapat meningkatkan kepuasan hidup seseorang. Hasil dari penelitian ini dapat menjadi rujukan untuk meningkatkan kualitas hidup manusia dengan berfokus pada cara dan gayanya di dalam memanfaatkan uang.
\end{abstract}

Kata kunci: gaya menggunakan uang, kepuasan hidup, pendapatan, pengeluaran, tabungan

\section{Life Satisfaction: A Review of the Financial Conditions and Money Spending Style}

\begin{abstract}
Factors of income and financial conditions greatly influence the Indonesian people's life satisfaction at this time. This study aims to analyze the influence of income, expenditure, savings, and the style of using money on life satisfaction. This study used a quantitative approach and involved 831 respondents selected using convenient sampling techniques. Data analysis was performed using $G^{*}$ Power software to see the effect size and multiple linear regression analysis techniques using the JASP software version 0.8.6. Data analysis results indicated that the amount of income, the amount of consumptive expenditure, and the number of assets significantly affected life satisfaction. The style of using money wisely and carefully affected life satisfaction. In contrast, the style of spending money and using cash in vain did not have a significant impact on life satisfaction. This study proves that controlled use of money, especially saving behavior for future needs, can increase one's life satisfaction. The results of this study can also be a reference for improving a person's quality of life by looking at the way he uses his money.
\end{abstract}

Keywords: expenses, income, life satisfaction, money spending styles, savings

\section{PENDAHULUAN}

Kepuasan hidup merupakan tujuan utama yang diinginkan setiap manusia. Kepuasan hidup dan kebahagiaan merupakan konsep psikologi yang banyak diteliti oleh para ahli untuk menggambarkan kondisi manusia dalam mencapai kualitas hidup yang diinginkan. Penelitian mengenai kepuasan hidup merupakan salah satu fokus utama dalam ilmu psikologi, namun semakin berkembang ilmu pengetahuan saat ini pembahasan mengenai kepuasan hidup juga dapat dilihat dalam perspektif ekonomi. Penelitian sebelumnya mengungkapkan, kebahagiaan dan kepuasan hidup dipengaruhi oleh faktor kontekstual tempat konsep tersebut diukur seperti kesejahteraan ekonomi rumah tangga, kesehatan, layanan publik, dan juga kondisi sosio komunitas yang ada (Argyle, 2003; Diener et al., 1999; Helliwell, 2006 dalam Sujarwoto, Tampubolon, \& Pierewan, 2018). Indonesia merupakan salah satu negara dengan kondisi kepuasan hidup yang tinggi (Gottfried, 2014). Berdasarkan survei mengenai kebahagiaan dan kepuasan hidup yang dimiliki 
oleh masyarakat Indonesia, 55 persen diantaranya menyatakan bahwa subjek penelitian berada pada posisi "sangat berbahagia", dan jumlah ini melebihi kondisi kebahagiaan pada negara lain bahkan pada negara-negara yang kaya seperti Inggris dan AS serta negara berkembang lainnya seperti India, Meksiko, dan Brasil (Gottfried, 2014). Hanya saja, indeks kebahagiaan ini cenderung menurun terus menerus dari 2015 hingga 2018 (Helliwell, Layard, \& Sachs, 2018). Hal ini ditunjukkan melalui ranking indeks kebahagiaan dan kepuasan hidup pada tahun 2015, Indonesia masuk dalam peringkat 74 , pada tahun 2016 peringkat Indonesia menurun menjadi peringkat 79, hingga pada tahun 2018 peringkat Indonesia semakin menurun dan mendapat peringkat 96 dari 193 negara di dunia (CNN Indonesia, 2018).

Hasil survei kebahagiaan global World Happiness Report tahun 2018 (Helliwell et al., 2018) menunjukkan kondisi ekonomi global suatu negara menentukan indeks kebahagiaan. Hal ini ditunjukkan dengan adanya perbedaan nilai kebahagiaan masyarakat dalam suatu negara yang memiliki kondisi ekonomi baik dan negara yang memiliki kondisi ekonomi buruk. Kondisi keuangan yang dipersepsikan positif, baik secara individu maupun secara kontekstual berdasarkan negara maupun daerah akan berkaitan dengan tingginya kebahagiaan masyarakat.

Kondisi ekonomi yang baik membuat masyarakat memiliki akses ke barang dan jasa yang berkaitan dengan hajat hidupnya (Sujarwoto et al., 2018). Kondisi kekayaan dan status ekonomi seseorang berpengaruh secara langsung terhadap kepuasan hidup yang membuat pengukuran mengenai keuangan menjadi indikator utama dalam menjelaskan kepuasan hidup (Johnson \& Krueger, 2006). Di Indonesia, salah satu dari sumber penurunan kebahagiaan adalan kondisi keuangan yang berupa angka GDP (Gross Domestic Products) per kapita, meskipun GDP memiliki keterbatasan dalam memprediksi kondisi ekonomi seseorang atau suatu keluarga karena tidak mengukur distribusi pendapatan seseorang secara aktual (Bergh, 2009).

Uang merupakan salah satu sumber daya terbatas yang dimiliki manusia. Pemanfaatan uang dapat menjadi determinan kepuasan ataupun ketidakpuasan dalam kehidupan manusia, termasuk memprediksi tingkat kebahagiaannya (Boyce, Brown, \& Moore, 2010). Ada beberapa karakteristik psikologis individu yang ikut memengaruhi persepsi terhadap uang dan kepuasan hidup, seperti yang dinyatakan oleh Chitchai, Senasu, dan Sakworawich (2020) bahwa orang yang memiliki kecintaan terhadap uang akan menunjukkan kepuasan hidup yang lebih tinggi atas kepemilikan uang dibandingkan saat memiliki status sosial dan ekonomi yang tinggi. Memiliki dan bisa menggunakan uang secara optimal mampu membuat seseorang untuk dapat menikmati banyak hal yang bermakna bagi dirinya. Uang juga memiliki peranan penting untuk membuat manusia memenuhi kebutuhannya. Pada akhirnya, hal ini akan berdampak secara psikologis terhadap kepuasan maupun ketidakpuasan hidup yang dijalaninya. Mogilner, Whillans, dan Business (2018) mengungkapkan, memiliki banyak uang membuat manusia cenderung merasa bahwa dirinya memiliki pengalaman hidup yang baik dan memuaskan.

Lebih lanjut, Boyce et al. (2010) menjelaskan bahwa penelitian mengenai uang dan kebahagiaan muncul dengan hasil yang bervariasi pada beberapa negara, meskipun ada pola yang umum bahwa terdapat pengaruh signifikan uang terhadap kebahagiaan, baik itu berupa kepuasan secara finansial maupun subjektif. Di negara dengan pendapatan rendah dan negara berkembang, kondisi keuangan memiliki pengaruh yang lebih besar terhadap kebahagiaan dan kesejahteraan psikologis. Hal ini ditunjukkan dengan semakin tinggi GDP, maka akan semakin tinggi indeks kebahagiaan warganya (Settle, 2014).

Temuan penelitian yang menarik mengenai kepuasan hidup pada masyarakat Indonesia dilakukan oleh Clark et al. (2017) yang menyatakan bahwa determinan besar dalam menentukan kepuasan hidup orang Indonesia adalah pendapatannya dibandingkan dengan determinan lain seperti kesehatan mental, pekerjaan, kondisi kesehatan fisik ataupun status terkait pasangan. Penelitian lain juga menunjukkan bahwa semakin baik kondisi pendapatan seseorang dari waktu ke waktu, maka tingkat kepuasan hidupnya juga semakin tinggi (Cheung \& Lucas, 2015). Hasil ini juga didukung oleh penelitian cross-cultural yang dilakukan oleh Johnson dan Krueger (2006) yang menunjukkan hasil bahwa kekayaan seseorang dan cara menggunakan uangnya memiliki kontribusi terhadap kesejahteraan subjektif dan kepuasan hidup masyarakat adat di Malaysia.

Ada beragam cara yang dapat dilakukan untuk memanfaatkan uang. Orang dapat menggunakan uangnya untuk membeli 
kesenangan, baik berupa barang, pengalaman, maupun membeli kemudahan untuk menjalankan aktivitas kesehariannya (Whillans et al., 2017). Namun, banyak juga orang yang berusaha menyimpan sebagian dari penghasilanya untuk memiliki tabungan dalam berbagai bentuk. Lebih lanjut, tabungan yang dimiliki seseorang akan memengaruhi kondisi psikologisnya berupa meningkatnya persepsi mengenai kesejahteraan (Maison et al., 2019).

Perilaku menabung secara umum diasosiasikan dengan pemenuhan rasa aman terhadap masa yang akan datang. Hal ini membuat seseorang bersedia menunda kesenangan yang mampu dibeli saat ini, untuk memastikan memiliki dana cadangan ketika menghadapi kesulitan di masa depan. Selanjutnya, pola ini dijelaskan melalui Teori Life-Cycle bahwa individu memaksimalkan utilitas dari waktu ke waktu dan menganggap bahwa pendapatan saat ini merupakan bentuk perdagangan sepanjang hidup (Xiao, Ford, \& Kim, 2011). Keputusan individu untuk memperlakukan uangnya akan sangat tergantung oleh jumlah total sumber daya (misalnya: pendapatan \& warisan) dan pola konsumsi yang diterapkan, serta kemungkinan akan memasuki siklus pensiun atau tidak produktif di masa tua. Oleh sebab itu, mereka berusaha untuk menabung di masa kerja agar bisa menghabiskannya secara maksimal di masa pensiun.

Namun, perilaku menabung belum terlalu populer di Indonesia. Hal ini didasarkan pada penelitian Arifin dan Anastasia (2017) yang menunjukkan 70 persen orang Indonesia tidak memiliki perencanaan menabung dan berinvestasi jangka panjang serta sedikitnya proporsi menabung dibandingkan dengan jumlah pendapatan selama sebulan. Oleh sebab itu, penelitian ini juga melibatkan variabel jumlah tabungan sebagai salah satu prediktor terhadap kepuasan hidup masyarakat Indonesia.

Variabel lain yang diteliti untuk menjelaskan kesejahteraan individu adalah terkait dengan gaya penggunaan uang (money spending style). Pada dasarnya uang merupakan sumber daya yang bersifat terbatas sehingga perilaku pemanfaatannya juga sangat bervariasi. Keputusan seseorang untuk membelanjakan uangnya untuk membeli sesuatu dan tidak menggunakannya untuk hal lainnya sangat dipengaruhi oleh banyak faktor.

Carter (2016) menyatakan bahwa keputusan membeli sesuatu sangat tergantung oleh preferensi natural individu dan juga memengaruhi persepsi setelah menggunakan uangnya. Penelitian-penelitian sebelumnya menunjukkan bahwa indikator objektif dari kondisi ekonomi mungkin tidak selalu secara akurat mencerminkan cara orang menilai dan mempersepsikan kondisi keuangan mereka. Sebagai contohnya dua orang yang memegang jumlah kekayaan yang sama mungkin melihatnya secara berbeda, tergantung oleh kebutuhan, harapan, ataupun pengalaman masa lalu (Klontz et al., 2011).

Kondisi keuangan, termasuk tabungan dan kebiasaan dalam memperlakukan uang memliki beberapa paradoks (Maison, 2019). Ada orang yang merasa kaya ketika memiliki pendapatan besar meskipun tidak memiliki tabungan. Ada juga orang yang merasa kaya ketika memiliki banyak aset meskipun juga memiliki banyak utang. Demikian pula dengan kondisi tabungan dan kebiasaan dalam berperilaku terkait uang. Berbagai persepsi dalam memaknai uang ini juga membuat perilaku penggunaan uang menjadi beragam.

Maison (2019) menyatakan bahwa terdapat empat jenis gaya menggunakan uang yaitu thrifty spending, belt tightening, happy spending, dan spendthrift. Pembagian gaya penggunaan uang ini berdasarkan pada klasifikasi faktor perilaku (spontan atau terkontrol) serta faktor emosional (emosi positif atau negatif). Happy Spending (senang berbelanja) adalah gaya penggunaan uang yang ditandai dengan kecenderungan menghabiskan uang dengan mudah dan pada saat yang sama, individu akan merasakan emosi positif. Individu tersebut dapat menikmati uang yang dihabiskan pada produk yang sudah dibeli, meskipun barang-barang tersebut tidak benar-benar diperlukan atau bahkan tidak masuk akal, namun hal tersebut dapat memberi kesenangan yang maksimal.

Spendthrift (berbelanja secara sia-sia) merupakan gaya penggunaan uang yang ada pada tingkat perilaku. Gaya ini hampir sama dengan happy spending, tetapi berbeda pada aspek emosionalnya (Maison, 2019). Perilaku penggunaan gaya ini lebih sering disertai dengan emosi negatif. Orang dengan gaya penggunaan uang spendthrift menunjukkan kurangnya kontrol atas keuangan, mengeluarkan uang di luar kemampuan mereka, serta ketidakmampuan untuk menunjukkan pengekangan dan menunda pembelian sampai benar-benar mampu. Gaya Spendthrift ditunjukkan saat manusia bersikap boros namun disertai dengan emosi negatif seperti rasa bersalah. 
Tightening the belt (gaya mengencangkan ikat pinggang) merupakan perilaku berhemat namun disertai dengan emosi negatif (Maison, 2019). Orang dengan gaya penggunanan uang ini membatasi pengeluaran karena subjek merasa memiliki uang terlalu sedikit, miskin, serta tidak mampu meraih kesenangan. Pada situasi ini, setiap pengeluaran terhubung dengan rasa bersalah, perasaan rendah diri, rasa tidak adil dan terluka sehingga membuat semua pembelian terasa tidak menyenangkan.

Thrifty spending (belanja hemat) gaya ini terkait dengan kontrol yang efektif atas perilaku penggunaan uang. Bagi orang yang berhemat, tidak menghabiskan uang adalah hal yang membuat mereka memiliki emosi positif. Hal ini menjadi pembeda dengan mereka yang memiliki gaya mengencangkan ikat pinggang. Orang-orang dengan preferensi gaya ini tidak menghabiskan uang yang mereka miliki karena mereka memiliki kontrol diri tingkat tinggi terhadap keinginan mereka, tidak mudah menyerah dengan hasrat berbelanja, mampu menunda kepuasan dari aktivitas berbelanja, serta mampu menempatkan proritas belanja sesuai dengan kepentingan. Orang dengan gaya hemat ini seringkali membatasi pengeluaran mereka saat ini agar mampu menggunakan uangnya untuk sesuatu yang lebih penting di masa depan, yang mana dapat memberi mereka lebih banyak kesenangan dan kepuasan.

Kajian mengenai keterkaitan antara kondisi ekonomi dengan kepuasan diri perlu untuk diulas lebih lanjut. Penelitian ini bertujuan untuk: (1) Mengidentifikasi kondisi keuangan yang terdiri atas pendapatan, pengeluaran, tabungan, dan gaya penggunaan uang pada masyarakat Indonesia; (2) Menganalisis pengaruh kondisi keuangan yang terdiri atas pendapatan, pengeluaran, tabungan, dan gaya penggunaan uang terhadap kepuasan hidup subjek.

\section{METODE}

Penelitian ini menggunakan pendekatan kuantitatif dengan desain cross-sectional. Data yang digunakan dalam penelitian ini merupakan data primer. Data primer diperoleh melalui selfreport menggunakan kuesioner terstruktur yang dilakukan secara daring. Pengambilan data dilakukan pada bulan Juli hingga September 2016, dengan responden adalah warga negara Indonesia. Penetapan jumlah sampel dalam penelitian ini dilakukan dengan menggunakan aplikasi $G^{*}$ Power versi 3.1 pada effect size sebesar 0,8 , jumlah sampel minimal adalah sebanyak 82 responden.

Pengambilan data dilakukan dengan metode non-probability sampling dengan teknik convenience sampling. Kelemahan dari teknik ini adalah sedikitnya kemampuan kontrol subjek penelitian oleh peneliti sehingga rawan memunculkan bias. Peneliti mengggunakan teknik ini karena kemudahannya baik dari segi waktu maupun sumber daya dibandingkan jika menggunakan teknik sampling lainnya. Untuk memastikan karakteristik sampel sesuai dengan karakteristik populasi yang dituju, peneliti memberikan deskripsi yang jelas mengenai karakteristik subjek dan mengeliminasi responden yang tidak memenuhi syarat sampel yang dituju.

Penelitian ini melibatkan 831 responden yang tersebar dari berbagai wilayah di Indonesia. Adapun kriteria usia responden yaitu minimal 17 tahun, dengan asumsi bahwa responden dewasa memiliki kemampuan untuk memahami nilai uang dan mampu menggunakannya sesuai dengan kebutuhan mereka. Karakteristik responden dalam penelitian ini juga dibatasi pada mereka yang merupakan Warga Negara Indonesia, bekerja dan memiliki besaran pendapatan bulanan yang cenderung tetap. Sebaran domisili responden dalam penelitian ini adalah 20,7 persen dari DKI Jakarta, 15,1 persen dari Jawa Barat, 10,2 persen dari Jawa Tengah, 16,4 persen dari Yogyakarta, 29,5 persen dari Jawa Timur, dan sisanya sebesar 8 persen dari berbagai daerah lainnya di Indonesia.

Variabel dependen dalam penelitian ini adalah kepuasan hidup yang didefinisikan sebagai evaluasi kognitif terhadap hidup seseorang. Variabel kepuasan hidup diukur menggunakan instrumen SWLS (Satisfaction With Life Scale) yang diadaptasi dari penelitian Pavot dan Diener (2008) dengan nilai reliabilitas ( $\alpha$ ) 0,804.

Alat ukur ini digunakan untuk menilai persepsi kognitif individu terhadap kepuasan hidupnya secara global, yang terdiri atas 5 butir pernyataan ( $1=$ Dalam banyak hal, hidup saya saat ini dekat dengan gambaran hidup ideal yang saya miliki", 2=Kondisi kehidupan saya memuaskan; $3=$ Saya puas dengan hidup saya; 4=Sejauh ini saya mendapatkan hal-hal penting yang saya inginkan dalam hidup; dan $5=$ Jika saya bisa mengulang kehidupan saya, saya tidak akan mengubah apapun) dengan skala pilihan jawaban 1 sampai 7 (1=sangat tidak setuju; $2=$ tidak setuju; $3=$ sedikit tidak setuju; $4=$ netral; $5=$ sedikit setuju; $6=$ setuju; dan 
$7=$ sangat setuju). Semakin tinggi skor total yang dihasilkan atas butir-butir pernyataan tersebut artinya skor kepuasan hidup juga semakin besar.

Variabel independen dalam penelitian ini terdiri atas variabel gaya penggunaan uang dari skala gaya penggunaan uang (money spending style) yang diadaptasi dari penelitian Maison (2019). Skala ini terdiri atas subskala menyenangi menghabiskan uang (happy spending) $(\alpha=0,95)$, subskala menghabiskan uang secara sia-sia (spendthrift) $(\alpha=0,540), \quad$ subskala menggunakan uang dengan cara hemat (thrifty spending $) \quad(\alpha=0,628)$, dan subskala mengencangkan ikat pinggang (tighten the belt) $(\alpha=0,514)$.

Setiap subskala berisi 4 pernyataan dengan respons 1 sampai 4 (1=sangat tidak setuju; 2=tidak setuju; 3=setuju; 4=sangat setuju). Subskala happy spending didefinisikan sebagai penggunaan uang secara mudah yang disertai emosi positif, terdiri atas empat butir pernyataan "Terkadang saya membeli sesuatu karena saya menyukainya, walaupun tidak membutuhkannya", "Ketika saya menyukai sesuatu, saya dapat menghabiskan banyak uang untuk hal tersebut", "Membeli suatu barang memberikan kenikmatan tersendiri, walaupun tidak ada alasan yang kuat", dan "Saya menghabiskan banyak uang tanpa banyak pertimbangan”. Semakin tinggi skor total responden terhadap butir-butir di atas menghasilkan skor happy spending yang semakin tinggi. Subskala spendthrift dalam didefinisikan sebagai gaya mudah mengeluarkan uang namun diikuti dengan emosi negatif, yang diukur melalui tiga butir pernyataan, yaitu "Saya menghabiskan uang untuk sesuatu yang tidak berguna, dan saya menyesalinya", "Ketika saya melihat sesuatu yang ingin saya miliki, saya tidak dapat mengontrol diri saya", dan "Ketika saya melihat sesuatu yang ingin saya miliki, saya tidak dapat mengontrol diri saya". Semakin tinggi skor total responden terhadap butir-butir di atas menghasilkan skor spendthrift yang semakin tinggi.

Subskala thrifty spending didefiniskan sebagai gaya membatasi pengeluaran yang diikuti dengan emosi positif. Gaya ini diukur menggunakan tiga butir pernyataan, yaitu "Karena saya menyimpan uang dengan baik, maka saya selalu memiliki uang pada saat-saat dibutuhkan", "Saya menabung karena saya tidak tahu kebutuhan saya dikemudian hari", dan "Saya mengontrol anggaran pribadi saya dengan baik sehingga saya memiliki tabungan yang cukup". Semakin tinggi skor total responden terhadap butir-butir di atas menghasilkan skor thrifty spending yang semakin tinggi. Subskala tighten the belt didefinisikan sebagai gaya penggunaan yang diupayakan seminim mungkin dan disertai emosi negatif ketika harus menggunakan uang. Gaya penggunaaan uang ini diukur oleh tiga butir pernyataan "Saya tidak merasa terganggu dengan produk-produk yang saya tidak bisa membelinya", "Saya rela untuk keluar masuk toko, untuk bisa mendapatkan harga yang paling murah", dan "Dalam rangka menghemat, saya memilih untuk belanja di pasar tradisional, atau toko-toko yang memberikan diskon". Semakin tinggi skor total responden terhadap butir-butir di atas menghasilkan skor tighten the belt yang semakin tinggi.

Variabel kondisi finansial dalam penelitian ini diukur melalui tiga aspek, yaitu pendapatan responden yang berkisar pada nilai 1 sampai dengan 5 (1=pendapatan perbulan kategori rendah di bawah Rp2.500.000,00; $2=$ pendapatan perbulan agak rendah yang berada pada rentang Rp2.501.000,00-Rp5.000.000,00; 3=pendapatan perbulan kategori agak tinggi di antara Rp5.001.000,00-Rp7.500.000,00; 4= pendapatan perbulan kategori tinggi yang berada pada rentang Rp7.501.000,00Rp10.000.000,00; 5=pendapatan perbulan dalam kategori sangat tinggi di atas Rp10.000.000). Kategori pendapatan yang digunakan dalam penelitian ini merujuk pada Badan Pusat Statistik (2015).

Variabel pengeluaran dalam penelitian ini diukur dengan respon 1 sampai dengan 5 (1=pengeluaran perbulan kategori rendah di bawah Rp2.500.000,00; 2=pengeluaran perbulan agak rendah di antara Rp2.501.000,00 -Rp5.000.000,00; 3=pengeluaran perbulan kategori cukup tinggi di antara Rp5.001.000,00 - Rp7.500.000,00; 4=pengeluaran perbulan kategori tinggi di antara Rp7.501.000,00-Rp10.000.000,00; dan $5=$ pengeluaran perbulan kategori sangat tinggi >Rp10.000.000 (BPS, 2015).

Variabel jumlah tabungan diukur dengan respon 1 sampai 5. Adapun pemaknaan untuk masing-masing respon, yaitu $1=$ menunjukkan jumlah tabungan kurang dari total pendapatan 1 bulan; 2=menunjukkan jumlah tabungan sedikit lebih besar dari 2 sampai 3 kali pendapatan bulanan; 3=menunjukkan jumlah tabungan bernilai lebih besar dari 4 sampai 6 kali pendapatan bulanan; 4=menunjukkan jumlah tabungan bernilai lebih besar dari 7 sampai 10 kali pendapatan bulanan; dan 5=menunjukkan 
jumlah tabungan bernilai di atas 10 kali lipat pendapatan bulanan. Analisis data untuk penelitian ini menggunakan teknik analisis regresi berganda dengan bantuan software Jeffreys's Amazing Statistics Program (JASP) versi 0.8.6.

\section{HASIL}

\section{Karakteristik Responden}

Responden yang terlibat dalam penelitian ini berjumlah 831 orang yang terdiri atas 490 perempuan dan 341 laki-laki. Responden perempuan berada pada rentang usia 19-60 tahun, sedangkan responden laki-laki berada pada rentang usia 18-87 tahun.

Berdasarkan tingkat pendidikan, mayoritas responden (53,3\%) merupakan lulusan Sekolah Menengah Atas (SMA/STM). Hampir sepertiga responden $(28,4 \%)$ yang memiliki pendidikan terakhir tingkat sarjana dan diploma. Lebih lanjut, hanya sekitar seperdelapan (12\%) responden yang memiliki jenjang pendidikan tingkat magister (S2) dan doktor (S3)

\section{Jumlah Pendapatan dan Pengeluaran}

Hasil penelitian memperlihatkan lebih dari 50 persen responden memiliki pendapatan bulanan kurang dari Rp2.500.000,00 dan hampir sepertiga $(30,6 \%)$ responden memiliki pendapatan bulanan berkisar antara Rp2.500.000,00 sampai Rp5.000.000,00. Hanya sekitar seperlima (19,4\%) responden yang memiliki pendapatan di atas Rp5.001.00000.

Berdasarkan jumlah pengeluaran perbulan, lebih dari setengah dari total responden memiliki pengeluaran bulanan kurang dari Rp2.500.000,00. Lebih dari seperempat responden $(28,1 \%)$ memiliki pengeluaran bulanan sebesar Rp2.501.000,00 sampai Rp5.000.000,00. Sisanya, kurang dari sepertujuh $(14,1 \%)$ yang memiliki pengeluaran bulanan >Rp5.000.000,00 (Tabel 1).

\section{Tabungan}

Berdasarkan jumlah tabungan yang dimiliki oleh seluruh responden, seperenam (15,9\%) diantaranya memiliki jumlah tabungan kurang dari total pendapatan selama 1 bulan, Mayoritas responden (75\%) memiliki jumlah tabungan antara 2 hingga 3 kali lipat pendapatan bulanan. Sisanya, 9,1 persen memiliki tabungan yang bernilai lebih dari 4 kali lipat pendapatan bulanan.
Tabel 1 Sebaran responden berdasarkan pendapatan dan Pengeluaran

\begin{tabular}{|c|c|c|c|}
\hline Variabel & Kategori & $\mathrm{n}$ & $\%$ \\
\hline \multirow[t]{5}{*}{ Pendapatan } & $\begin{array}{l}\text { Rendah } \\
(<\text { Rp2.500.000,00) }\end{array}$ & 416 & 50,1 \\
\hline & $\begin{array}{l}\text { Agak Rendah } \\
\text { (Rp2.500.000,00 } \\
\text { s/d } \\
\text { Rp5.000.000,00) }\end{array}$ & 254 & 30,6 \\
\hline & $\begin{array}{l}\text { Cukup tinggi } \\
\text { (Rp5.001.000,00 } \\
\text { s/d } \\
\text { Rp7.500.000,00) }\end{array}$ & 54 & 6,5 \\
\hline & $\begin{array}{l}\text { Tinggi } \\
\text { (Rp7.501.000,00 } \\
\text { s/d } \\
\text { Rp10.00.000,00) }\end{array}$ & 52 & 6,3 \\
\hline & $\begin{array}{l}\text { Sangat tinggi } \\
(>\text { Rp10.000.000,00) }\end{array}$ & 55 & 6,6 \\
\hline \multirow[t]{5}{*}{ Pengeluaran } & $\begin{array}{l}\text { Rendah } \\
(<\text { Rp2.500.000,00) }\end{array}$ & 480 & 57,8 \\
\hline & $\begin{array}{l}\text { Agak Rendah } \\
\text { (Rp2.500.000,00 } \\
\text { s/d } \\
\text { Rp5.000.000,00) }\end{array}$ & 234 & 28,1 \\
\hline & $\begin{array}{l}\text { Cukup tinggi } \\
\text { (Rp5.001.000,00 } \\
\text { s/d } \\
\text { Rp7.500.000,00) }\end{array}$ & 38 & 4,6 \\
\hline & $\begin{array}{l}\text { Tinggi } \\
\text { (Rp7.501.000,00 } \\
\text { s/d } \\
\text { Rp10.00.000,00) }\end{array}$ & 40 & 4,8 \\
\hline & $\begin{array}{l}\text { Sangat tinggi } \\
(>\text { Rp10.000.000,00) }\end{array}$ & 39 & 4,7 \\
\hline \multirow[t]{6}{*}{ Tabungan } & $\begin{array}{l}\text { Sedikit ( }<1 \text { bulan } \\
\text { pendapatan } \\
\text { bulanan) }\end{array}$ & 132 & 15,9 \\
\hline & $\begin{array}{l}\text { Agak Sedikit (2-3 } \\
\text { kali pendapatan } \\
\text { bulanan) }\end{array}$ & 623 & 75 \\
\hline & $\begin{array}{l}\text { Cukup ( } 4-6 \text { kali } \\
\text { pendapatan } \\
\text { bulanan) }\end{array}$ & 45 & 5,4 \\
\hline & $\begin{array}{l}\text { Lebih dari cukup ( } 7- \\
8 \text { kali pendapatan } \\
\text { bulanan) }\end{array}$ & 24 & 2,9 \\
\hline & $\begin{array}{l}\text { Banyak (>8 kali } \\
\text { pendapatan } \\
\text { bulanan) }\end{array}$ & 7 & 0,8 \\
\hline & Total & 831 & 100 \\
\hline
\end{tabular}

Keterangan: $\mathrm{n}=$ jumlah; \%=persen

\section{Gaya Penggunaan Uang dan Kepuasan Hidup Subjektif}

Mayoritas responden melaporkan memiliki gaya penggunaan uang happy spending pada kategori menengah sebanyak 94 persen. 
Tabel 2 Nilai minimum, maksimum, rataan dan standar deviasi gaya penggunaan uang dan kepuasan hidup subjektif

\begin{tabular}{lrrr}
\hline \multicolumn{1}{c}{ Variabel } & Min & Maks & Rataan \pm SD \\
\hline $\begin{array}{l}\text { Gaya penggunaan } \\
\text { uang }\end{array}$ & & & \\
$\quad$ Happy spending & 0 & 16 & $8,831 \pm 2,216$ \\
$\quad$ Tighten the belt & 0 & 12 & $8,812 \pm 1,554$ \\
$\quad$ Spendthrift & 0 & 12 & $6,087 \pm 1,732$ \\
Thrifty spending & 0 & 12 & $9,13 \pm 1,567$ \\
\hline Kepuasan Hidup & 1 & 100 & $73,989 \pm 16,74$ \\
\hline Keterangan: Min=minimum; Maks=maksimum
\end{tabular}

Sisanya sebanyak 6 persen melaporkan bahwa mereka menyukai menghabiskan uang dengan cepat dan merasakan emosi positif pada saat yang sama.

Mayoritas gaya tighten the belt yang dilaporkan oleh responden berada pada kategori tinggi sebesar 64 persen. Hal ini menunjukkan bahwa lebih dari separuh responden merasa memliki gaya berhemat dalam menggunakan uang, yang juga disertai oleh emosi negatif ketika melakukannya.

Sebaran gaya penggunaan uang thrifty spending yang identik dengan perilaku berhatihati dalam menggunakan uang dan disertai perasaan positif, direspon dalam kategori tinggi oleh mayoritas responden (72,3\%). Sementara sisanya sebanyak 19 persen melaporkan bahwa mereka memiliki gaya penggunaan uang thrifty spending pada kategori menengah, dan sisanya sebesar 8,7 persen melaporkan gaya thrifty spending yang tergolong rendah

Selanjutnya, sebagian besar responden (76\%) menerapkan gaya penggunaan uang spendthrift (berbelanja secara sia-sia yang disertai emosi negatif) terkategori sedang. Seperlima responden (20\%) melaporkan gaya penggunaan uang spendthrift dalam kategori tinggi dan sisanya terkategori rendah.

Lebih lanjut, hasil analisis menunjukkan bahwa lebih dari setengah responden memiliki kepuasan hidup yang cenderung tinggi (65\%). Sisanya, lebih dari sepertiga (35\%) responden melaporkan kondisi kepuasan hidup subjektif yang dirasakan berada pada kategori rendah dan sedang. Kepuasan hidup subjektif dalam penelitian ini menggambarkan seseorang yang memiliki evaluasi kognitif terhadap hidupnya. Artinya, mayoritas responden memiliki persepsi positif dan merasa puas dengan situasi kehidupannya saat ini (Tabel 2).
Tabel 3 Koefisien uji pengaruh gaya penggunaan uang, pendapatan, pengeluaran, dan tabungan terhadap kepuasan hidup

\begin{tabular}{lrrr}
\hline \multicolumn{1}{c}{ Variabel } & $B$ & $\beta$ & Sig. \\
\hline Konstanta & 16,119 & & $<0,001$ \\
\hline Gaya penggunaan uang & & & \\
$\quad$ Happy spending & 0,015 & 0,006 & 0,872 \\
Tighten the Belt & $-0,269$ & $-0,075$ & 0,032 \\
Thrifthy spending & 0,642 & 0,182 & $<0,001$ \\
$\quad$ Spendthrift & $-0,007$ & $-0,002$ & 0,951 \\
\hline Pendapatan & 0,739 & 0,142 & 0,003 \\
\hline Pengeluaran & 0,755 & 0,123 & 0,009 \\
\hline Tabungan & 0,718 & 0,084 & 0,013 \\
\hline
\end{tabular}

\section{Pengaruh Gaya Penggunaan Uang, Pendapatan, Pengeluaran, dan Tabungan terhadap Kepuasan Hidup}

Analisis regresi dalam penelitian ini dilakukan setelah melalui uji asumsi yang meliputi uji normalitas, uji heterokedastisitas, dan uji linieritas. Dari hasil uji asumsi ini, seluruh asumsi terpenuhi sehingga tahap selanjutnya dari analisis regresi dapat dilanjutkan. Hasil analisis data menunjukkan model cocok $\left(p<0,001, \quad R^{2}=0,108\right)$ dan variabel prediktor dalam model regresi yang dibangun memiliki koefisien determinasi sebesar 0,108. Artinya, model regresi ini dapat menjelaskan 10,8 persen pengaruh variabel-variabel dependen terhadap kepuasan hidup, sementara sisanya sebesar 89,20 persen berasal dari faktor-faktor lain yang memengaruhi kepuasan hidup. Informasi mengenai parameter dalam model menunjukkan bahwa dari tiga sub variabel kondisi keuangan yang diduga memiliki pengaruh terhadap kepuasan hidup, ketiganya memiliki pengaruh yang signifikan. Pengeluaran responden $(B=0,755, \quad S E=0,289, \quad t=0,123$, $p=, 009)$ berkontribusi secara signifikan dalam menjelaskan kepuasan hidup. Hal ini dapat diartikan bahwa peningkatan satu tingkat dalam pengeluaran responden akan meningkatkan skor kepuasan hidup sebesar 0,755.

Variabel pendapatan responden $(B=0,739$, $S E=0,248, t=0,142, p=, 003$ ) dan variabel jumlah tabungan $(B=0,718, \quad S E=0,289, \quad t=0,084$, $p=, 013$ ) juga menunjukkan kontribusi secara signifikan dalam menjelaskan kepuasan hidup. Hal ini dapat diartikan bahwa peningkatan satu tingkat dalam pendapatan akan meningkatkan skor kepuasan hidup sebar 0,739, dan peningkatan satu tingkat jumlah tabungan akan meningkatkan skor kepuasan hidup sebesar 0,718 (Tabel 3). 
Berdasarkan pada model regresi yang dibangun, dari empat sub variabel gaya penggunaan uang yang diprediksi memiliki pengaruh terhadap kepuasan hidup, hanya dua yang memiliki pengaruh signfikan, yaitu gaya berbelanja hemat (thrifty spending) dan mengencangkan ikat pinggang (tightgen the belt). Peningkatan satu satuan pada gaya berbelanja hemat (thrifty spending) $(B=0,642$, $S E=0,125, \quad t=0,182, \quad p=<, 001) \quad$ akan meningkatkan skor kepuasan hidup sebesar 0,642 . Selain itu, peningkatan satu satuan pada gaya penggunaan uang $(B=-0,269, S E=0,126$, $t=-0,075, p=0,032$ ) akan berkontribusi terhadap penurunan kepuasan hidup sebesar 0,269. Gaya penggunaan uang happy spending $(B=0,015, \quad S E=0,094, \quad t=0,006, \quad p=, 872) \quad$ dan spendthrift ( $B=-0,007, \quad S E=0,120, \quad t=-0,002$, $p=0,951)$ menunjukkan hasil kontribusi yang tidak signifikan dalam menjelaskan kepuasan hidup.

\section{PEMBAHASAN}

Hasil dari penelitian ini menggambarkan bahwa kondisi keuangan dan gaya menggunakan uang yang dimiliki seseorang akan turut menentukan kepuasan hidupnya secara umum. Semakin tinggi jumlah pendapatan, jumlah konsumsi bulanan, dan jumlah tabungan, maka kepuasan hidup subjektifnya juga akan semakin tinggi. Temuan dari penelitian ini menguatkan pendapat dari Settle (2014) dan Clark et al. (2017) bahwa semakin besar pendapatan maka indeks kebahagiaan juga akan semakin tinggi. Hal ini menunjukkan, semakin kuat kondisi ekonomi seseorang, yaitu memiliki pendapatan yang besar, maka kemampuan untuk memenuhi kebutuhannya juga akan semakin kuat. Selain itu, ketika jumlah pengeluaran atau jumlah konsumsi yang semakin besar, maka akan muncul persepsi positif tentang hidup. Penelitian ini juga menguatkan pendapat dari Xiao et al. (2011) bahwa perilaku menabung akan memberikan rasa puas karena ketika menabung manusia akan memiliki persepsi rasa aman untuk hidupnya di masa yang akan datang. Gaya penggunaan uang secara hemat dan berhati-hati juga memiliki pengaruh yang signifikan terhadap kepuasan hidup. Hal ini ditunjukkan bahwa semakin besar dorongan untuk menggunakan uang secara berhati-hati (baik itu dilakukan dengan emosi positif maupun dengan emosi negatif), maka akan lebih puas dalam hidup. Hal ini menunjukkan bahwa kemungkinan aspek emosi tidak akan terlalu berpengaruh untuk membantu seseorang memiliki persepsi positif atas hidupnya, khususnya dalam evaluasi yang bersifat jangka panjang. Sebaliknya, menggunakan uang dengan berhati-hati melalui pertimbangan rasional akan lebih meningkatkan kepuasan hidup. Sejalan dengan penelitian Johnson dan Krueger (2006), kontrol atas diri memiliki pengaruh sebagai mediasi antara kondisi keuangan aktual dengan kepuasan kerja. Oleh karena itu, dapat dikatakan bahwa semakin besar kontrol seseorang atas keinginannya, maka aspek kepuasan hidup akan mudah tercapai.

Hasil yang menarik dari penelitian ini yaitu secara parsial, gaya senang berbelanja, yang juga diartikan bahwa seseorang menghabiskan seluruh uangnya untuk berbelanja dan mendapatkan kesenangan dari perilaku tersebut, ternyata tidak memiliki pengaruh signifikan terhadap kepuasan hidup. Hal ini menjadi menarik karena pada penelitian lain, banyak orang justru mendapatkan rasa senang saat menghabiskan uang yang dimiliki untuk membeli barang-barang yang mereka inginkan (Mogilner et al., 2018). Temuan kedua yang tidak kalah pentingnya, yaitu gaya menggunakan uang secara sia-sia (spendthrift) juga tidak memiliki pengaruh signifikan terhadap kepuasan hidup.

Hasil analisis memperlihatkan bahwa besaran pendapatan, pengeluaran, maupun besaran tabungan memiliki pengaruh yang signifikan terhadap kepuasan hidup secara keseluruhan. Hal ini bermakna bahwa orang dengan pendapatan besar akan memiliki persepsi positif terhadap hidup mereka, demikian pula dengan orang-orang yang menggunakan uangnya dalam jumlah besar, serta mereka yang juga memiliki jumlah tabungan yang besar. Hasil ini menguatkan hasil penelitian dari Sengupta et al. (2012) mengenai kondisi finansial dan kebahagiaan di New Zealand bahwa pendapatan memiliki korelasi positif yang signifikan dengan kepuasan hidup dan kebahagiaan. Hasil dari penelitian ini juga memberikan kontribusi tambahan bagi literatur mengenai pengaruh kondisi keuangan terhadap kepuasan hidup maupun kesejahteraan psikologis bagi setiap individu, mengingat penelitian mengenai hubungan antara pendapatan dengan kepuasan dalam hidup menunjukkan hasil yang berbeda-beda pada banyak negara (Wu, 2019).

Gaya menggunakan uang yang memiliki pengaruh signifikan dalam penelitan ini adalah gaya hemat (mengencangkan ikat pinggang) dan gaya menggunakan uang secara berhatihati (thrifty). Individu yang memiliki gaya penggunaan uang secara cermat dan berhatihati (thrifty) memandang bahwa uang 
merupakan sumber daya yang terbatas sehingga mereka akan banyak melakukan pertimbangan sebelum memutuskan akan membeli barang. Perilaku ini membuat responden memiliki persepsi positif ketika mengevaluasi tindakannya karena telah mampu memanfaaatkan sumber daya finansial secara optimal. Demikian pula dengan kebiasaan menggunakan uang secara hemat yang juga berpengaruh positif secara signifikan terhadap kepuasan hidup.

Subjek yang memiliki gaya menggunakan uang secara hemat cenderung untuk mengevaluasi pilihan produk yang dibutuhkan atau inginkan dan membandingkan beberapa produk sejenis untuk memilih harga yang termurah sebelum membelinya. Perilaku ini membuat seseorang merasa telah melakukan pengambilan keputusan yang efektif dalam menggunakan uangnya sehingga responden bisa memanfaatkan sisa uangnya secara bermanfaat seperti misalnya membeli barang lain ataupun menabung. Perasaan telah mengelola keuangan secara efektif dan efisien inilah membuat seseorang yang memiliki gaya hemat dalam menggunakan uang memiliki kepuasan hidup subjektif yang lebih tinggi dibandingkan mereka yang menyadari bahwa mereka bertindak boros dan hanya bersenangsenang dengan uangnya. Hasil dari penelitian ini juga menguatkan gagasan Strömbäck et al. (2017) yang menyatakan bahwa kontrol diri seseorang dalam membuat keputusan finansial akan berpengaruh terhadap kesejahteraan finansial dan psikologisnya.

Penelitian Arifin dan Anastasia (2017) mengenai perilaku finansial menunjukkan bahwa keputusan membeli barang atau berbelanja pada dasarnya banyak melibatkan faktor emosional, bukan hanya dipengaruhi faktor kognitif atas berbagai pertimbangan. Hal ini menjadi penjelasan mengapa perilaku penggunaan uang dengan boros untuk bersenang-senang maupun terlalu hemat membuat seseorang bertindak tidak realistis terhadap kebutuhannya. Dunn, Gilbert, dan Wilson (2011) menyatakan bahwa untuk mendapatkan kebahagiaan dalam menggunakan uang, seseorang perlu membandingkan dan berpikir panjang mengenai pembelian dan dampak sesudah pembelian dilakukan. Emosi yang sesaat dirasakan ketika menggunakan uang cenderung tidak bertahan lama. Ketika perasaan senang karena membeli sesuatu dan membeli tanpa pertimbangan cenderung membuat sesorang merasa menyesal, demikian pula sebaliknya.
Lebih lanjut, seseorang yang merasa membutuhkan membeli sesuatu namun cenderung menahannya karena memiliki kecenderungan menyesal ketika berbelanja, orang tersebut akan mengalami rasa tidak puas. Jika dikaitkan dengan kepuasan hidup yang merupakan evaluasi seseorang terhadap berbagai aspek hidup dan sifatnya mengarah pada kualitas kehidupan dengan jangka waktu relatif panjang, maka kebiasaan menggunakan uang sekedar untuk kesenangan, menghabiskan uang tanpa pertimbangan, maupun secara ekstrim berusaha menahan keinginan berbelanja, dapat membuat seseorang kurang memiliki persepsi positif terhadap kualitas hidupnya. Selain itu, perilaku menghabiskan uang untuk hal yang tidak berguna berpotensi membuat seseorang menyesali keputusan pembelian yang telah dilakukan. Situasi seperti ini yang memungkinkan menjadi penjelasan mengapa gaya penggunaan uang secara boros maupun hemat berlebihan tidak berkontribusi positif terhadap kepuasan hidup.

Pendapatan yang besar juga membuat seseorang memiliki penilaian objektif yang baik terhadap hidupnya, meskipun tidak selalu berhubungan dengan kesejahteraan psikologis (subjective well-being) ataupun kepuasan secara emosional (Kahneman \& Deaton, 2010). Seseorang dengan kondisi ekonomi yang baik dalam hal pendapatan cenderung memiliki tingkat kepuasan yang tinggi ketika diminta mengevaluasi kualitas hidupnya. Pendapatan yang tinggi membuat seseorang memiliki pilihan untuk mengggunaka uangnya sesuai dengan yang mereka butuhkan. Orang-orang dengan tingkat pendapatan yang baik memiliki akses untuk merespon secara tepat atas beragam persoalan yang dihadapi (misalnya: membeli obat ketika sakit atau membeli sesuatu untuk keluarganya yang membuat mereka merasa bahagia). Kondisi sebaliknya untuk orang-orang yang memiliki tingkat penghasilan yang rendah, mereka cenderung merasa terluka secara emosi karena mereka tidak memiliki kemampuan untuk menyelesaikan persoalan yang mereka hadapi jika hal tersebut berkaitan dengan kebutuhan akan uang.

Selanjutnya, pengeluaran yang dipersepsikan sebagai pemenuhan kebutuhan juga turut memiliki pengaruh terhadap kualitas hidup serta kebahagiaan. Hasil ini sejalan dengan temuan dari penelitian $\mathrm{Wu}$ (2019) yang menyatakan pendapatan dan pengeluaran konsumtif memiliki pengaruh linear dengan kebahagiaan. Hal ini dijelaskan oleh Wu (2019) melalui Social 
Comparison Theory bahwa ketika sesorang memiliki kemampuan untuk membeli barangbarang dan jasa yang memiliki nilai lebih dibandingkan orang lain, maka hal tersebut akan membantunya untuk memiliki perasaan puas yang lebih besar. Namun, pengeluaran yang dikatakan memiliki hubungan dengan kepuasan hidup dan dapat dijelaskan melalui Social Comparison Theory adalah pengeluaran konsumsi yang sifatnya merupakan kebutuhan konsumsi sekunder dan bukan merupakan kebutuhan pokok.

Wu (2019) juga menjelaskan bahwa nilai konsumsi adalah prediktor yang lebih akurat untuk menggmbarkan kepuasan hidup dibandingkan variabel lain terkait kondisi keuangan karena tiga hal: (1) menggambarkan kondisi actual mengenai kemampuan ekonomi seseorang (2) pengeluaran konsumtif merupakan prediktor yang akurat mengenai kondisi ekonomi seseorang dalam jangka panjang, dan (3) pengukuran pengeluaran konsumtif lebih mudah diukur dibandingkan dengan pendapatan. Carter (2016) juga menjelaskan bawa mengeluarkan uang untuk pembelian tertentu yang diinginkan akan memberikan emosi yang positif setelahnya.

Kondisi tabungan yang memiliki pengaruh signifikan terhadap kepuasan hidup, dijelaskan oleh Klontz et al. (2011). Perilaku penggunaan uang seperti menabung dan berhemat, meskipun pada taraf tertentu membuat seseorang merasa cemas dan waspada, namun juga meningkatkan rasa aman terhadap kondisi finansial yang dihadapi. Adanya tabungan juga membuat seseorang merasa lebih aman dan siap menghadapi kemungkinan-kemungkinan dalam hidup di masa yang akan datang ketika mereka berada dalam situasi finansial yang tidak terlalu optimal. Seseorang yang menabung biasanya menyadari bahwa ada kemungkinan situasi sulit di masa depan yang membuat mereka membutuhkan dana lebih dari pendapatan (misalnya: ketika sakit, ada keluarga yang membutuhkan, ataupun ketika masuk dunia pensiun) sehingga pada saat itu mereka akan tetap mampu hidup dengan baik karena memiliki tabungan yang sudah disiapkan jauhjauh hari. Orang yang memiliki tabungan juga akan memiliki kesiapan lebih untuk menghadapi situasi darurat yang saat ini belum terbayangkan.

Pengaruh tabungan terhadap kepuasan hidup juga dijelaskan oleh Brown dan Gray (2016) yang menyatakan bahwa kondisi aset seseorang (kondisi kekayaan dikurangi utang dan pengeluaran) memiiki pengaruh yang signifikan terhadap kepuasan hidup dan kesejahteraan psikologis seseorang. Lebih lanjut, hal ini juga dijelaskan melalui Social Comparison Theory bahwa ketika orang mengetahui bahwa aset yang dimiliki lebih besar daripada rata-rata orang yang menjadi referensinya, maka ia akan memiliki kepuasan hidup dan kesejahteraan psikologis yang lebih besar. Jumlah tabungan yang besar juga berimpilikasi terhadap rasa aman seseorang karena akan timbul rasa memiliki "cash on hand" yang membuatnya fleksibel dalam membuat keputusan finansial terkait hidupnya (Ruberton, Lyubomirsky, \& Gladstone, 2016).

Berdasarkan penjelasan-penjelasan di atas, dapat disimpulkan bahwa ada keterkaitan antara kondisi keuangan (pendapatan, pengeluaran maupun kondisi tabungan) dan gaya menghabiskan uang terhadap kepuasan hidup. Semakin baik kondisi keuangan yang ditandai dengan semakin besar pendapatan, semakin mampu membelanjakan uang dengan optimal, serta semakin besar dan baik kondisi tabungan, dan gaya penggunaan uang yang tepat maka hal tersebut akan berkaitan erat dengan kepuasan hidup. Meskipun demikian, ada beberapa penelitian juga yang menyebutkan bahwa kepuasan hidup dan kebahagiaan terkait dengan kondisi keuangan tidak hanya dapat dijelaskan dari gaya penggunaan uang, melainkan juga alasan uang tersebut dihabiskan.

Dunn et al. (2011) dalam penelitiannya menyebutkan bahwa penggunaan uang dapat berujung pada kebahagiaan apabila: (1) uang digunakan untuk 'membeli' pengalaman (bukan barang material); (2) menggunakan uang untuk membahagiakan/menguntungkan orang lain, bukan hanya dirinya sendiri; (3) membeli lebih banyak kesenangan-kesenangan kecil, bukan sedikit kesenangan-kesenangan besar; (4) uang menjadi jaminan untuk menghindari biaya-biaya terkait asuransi yang sangat besar; (5) memiliki uang namun mampu menunda konsumsi; (6) mempertimbangkan efek lanjutan terhadap suatu pembelian terhadap kondisi sehari-hari; (7) membeli dengan perbandingan atas beberapa barang yang tersedia; (8) memperhatikan kebahagiaan orang lain untuk mencapai kebahagiaan dalam membeli barang. Penelitian ini menguatkan temuan-temuan dari penelitian sebelumnya bahwa secara umum, kekayaan dan cara menggunakan uang memiliki pengaruh terhadap kondisi psikologis seseorang.

\section{SIMPULAN DAN SARAN}


Secara umum, terdapat pengaruh kondisi ekonomi dari segi pendapatan, pengeluaran, dan jumlah tabungan terhadap kepuasan hidup. Gaya penggunaan uang, khususnya gaya menggunakan uang secara hemat juga memiliki pengaruh signifkan secara positif terhadap kepuasan hidup. Sebaliknya, gaya penggunaan uang mengencangkan ikat pinggang berpengaruh secara negatif terhadap kepuasan hidup.

Adapun upaya yang dapat dilakukan dalam rangka meningkatkan kepuasan hidup masyarakat yaitu melalui dua hal berikut. Pertama, meningkatkan kondisi ekonomi secara keseluruhan yang mencakup peningkatan pendapatan, peningkatan kemampuan ekonomi untuk konsumsi, dan peningkatan jumlah tabungan ataupun aset. Kedua, melatih gaya menggunakan uang secara hemat dan berhati-hati. Pemerintah ataupun kepala keluarga dapat mulai melakukan upaya edukasi untuk mengenalkan konsep berbelanja dengan pertimbangan matang untuk melatih masyarakat umum dan orang terdekatnya agar mampu menggunakan sumber daya finansialnya secara bijak dan efektif sehingga berdampak pada kepuasan hidup mereka. Upaya ini dapat dilakukan dengan psikoedukasi mengenai konsep uang sebagai sumber daya yang terbatas sehingga pemanfaatannya dalam memenuhi kebutuhan manusia juga perlu dilakukan secara cermat dan berhati-hati untuk bisa meningkatkan kualitas hidup manusia.

Untuk penelitian-penelitian selanjutnya, peneliti menyarankan agar mempertimbangkan pengklasifikasian variabel kondisi keuangan lain seperti kelas ekonomi, jenis pengeluaran bulanan (untuk pengeluaran dasar seperti makanan dan cicilan, atau pengeluaran yang sifatnya sekunder seperti gaya hidup), serta besaran dana yang disisihkan untuk tabungan jangka pendek ataupun investasi jangka panjang atau menengah. Hal ini perlu dilakukan mengingat makna uang bukan hanya terbatas pada besaran nominal, tetapi juga pada manfaatnya untuk digunakan pada berbagai aktifitas keseharian. Selain itu, penelitian selanjutnya dapat mempertimbangkan mengenai informasi peruntukan pembelanjaan dengan dasar penelitian bahwa jika seseorang menghabiskan uang untuk orang lain yang memiliki relasi dekat dengan mereka, hal tersebut akan menghasilkan kebahagiaan yang lebih besar daripada ketika mereka menghabiskan uangnya untuk memberi sesuatu kepada orang yang relasinya lebih jauh. Penelitian selanjutnya juga bisa dikaitkan dengan pembahasan soal pembelian barang yang memiliki kecocokan dengan kepribadian individunya. Saran ini sejalan dengan pendapat yang menyatakan bahwa ketika individu membelanjakan uangnya untuk membeli produk yang sesuai dengan karakteristik kepribadiannya, maka penggunaan uang diasosiasikan dengan kebahagiaan.

\section{DAFTAR PUSTAKA}

Arifin, A. Z., \& Anastasia, I. (2017). The affect of financial atittude, locus of control and income on financial behavior. International Conference on Economic, Business, and Accounting, 1(1), 92-92.

Bergh, J. C. J. M. V. D. (2009). The GDP paradox. Journal of Economic Psychology, 30(2), 117-135. doi:https://doi.org/ 10.1016/j.joep.2008.12.001.

Boyce, C. J., Brown, G. D. A., \& Moore, S. C. (2010). Money and happiness: Rank of income, not income, affects life satisfaction. Psychological Science, 21(4), 471-475. doi:https://doi.org/10.1177 /0956797610362671.

[BPS] Badan Pusat Statistik. (2015). Statistik 70 Tahun Indonesia Merdeka. Jakarta, ID: Badan Pusat Statistik.

Brown, S., \& Gray, D. (2016). Household finances and well-being in Australia: An empirical analysis of comparison effects. Journal of Economic Psychology, 53, 1736. j.joep.2015.12.006.

doi:https://doi.org/10.1016/

Carter, A. D. (2016). Mechanical reliability. London, UK: Macmillan International Higher Education.

Cheung, F., \& Lucas, R. E. (2015). When does money matter most? Examining the association between income and life satisfaction over the life course. Psychology and Aging, 30(1), 120.

Chitchai, N., Senasu, K., \& Sakworawich, A. (2020). The moderating effect of love of money on relationship between socioeconomic status and happiness. Kasetsart Journal of Social Sciences, 41(2), 336-344. doi:https:// doi.org/10.1016/j.kjss.2018.08.002.

Clark, A. E., Flèche, S., Layard, R., Powdthavee, N., \& Ward, G. (2017). The key determinants of happiness and misery.

CNN Indonesia. (2018, Maret 29). Studi: Rangking kebahagiaan Indonesia di dunia 'jeblok'. Retrieved from 
https://www.cnnindonesia.com/gayahidup/20180329074022-277-286709/studirangking-kebahagiaan-indonesia-di-duniajeblok.

Dunn, E. W., Gilbert, D. T., \& Wilson, T. D. (2011). If money doesn't make you happy, then you probably aren't spending it right. Journal of Consumer Psychology, 21(2), 115-125. Doi:https://doi.org/10.1016 /j.jcps.2011.02.002.

Gottfried, G. (2014). Global happiness report. Retrieved from https://www.ipsos.com /en/global-happiness-report.

Helliwell, J. F., Layard, R. \& Sachs, J. D. (2018). World happiness report 2018. Retrieved from https://www.eur.nl/esaa /media/2018-03-worldhappinessreport 2018.

Johnson, W., \& Krueger, R. F. (2006). How money buys happiness: Genetic and environmental processes linking finances and life satisfaction. Journal of personality and social psychology, 90(4), 680.

Kahneman, D., \& Deaton, A. (2010). High income improves evaluation of life but not emotional well-being. Proceedings of the national academy of sciences, 107(38), 16489-16493.

Klontz, B., Britt, S. L., Mentzer, J., \& Klontz, T. (2011). Money beliefs and financial behaviors: Development of the klontz money script inventory. Journal of Financial Therapy, 2(1), 1-22. doi:https://doi.org/10.4148/jtt.v2i1.451.

Maison, D. (2019). The psychology of financial consumer behavior. Berlin, DE: Springer, Cham. doi:https://doi.org/10.1007/978-3030-10570-9.

Maison, D., Marchlewska, M., Sekścińska, K., Rudzinska-Wojciechowska, J., \& Łozowski, F. (2019). You don't have to be rich to save money: On the relationship between objective versus subjective financial situation and having savings. Plos one, 14(4), 1-15. doi:https://doi.org/ 10.17605/OSF.IO/H7RK4.

Mogilner, B. C., Whillans, A., \& Business, $H$. (2018). Time, money, and subjective wellbeing. Handbook of Well-Being, 495-510. Retrieved from https://www.hbs.edu/faculty /Pages/item. aspx?num=53781.

Pavot, W., \& Diener, E. (2008). The satisfaction with life scale and the emerging construct of life satisfaction. The journal of positive psychology, 3(2), 137-152.

Ruberton, P. M., Lyubomirsky, S., \& Gladstone, J. (2016). How your bank balance buys happiness: The importance of "cash on hand" to life satisfaction. Emotion, 16(5), 575-580. doi:https://doi.org/10.1037 /emo0000184.

Sengupta, N., Osborne, D., Houkamau, C., Hoverd, W., Wilson, M., Halliday, L., Sibley, C. (2012). Income and the fulfillment of basic needs. New Zealand Journal of Psychology, 41(2). Retrieved from http://www.psychology.org.nz/wpcontent/uploads/Sibley4.pdf.

Settle, R. (2014). Does money truly buy happiness? A study of 56 countries' levels of happiness and the contributing factors. Papers \& Publications: Interdisciplinary Journal of Undergraduate Research, 3(1), 11.

Strömbäck, C., Lind, T., Skagerlund, K., Västfjäll, D., \& Tinghög, G. (2017). Does self-control predict financial behavior and financial well-being?. Journal of Behavioral and Experimental Finance, 14, 30-38. doi:https://doi.org/10.1016/j.jbef.2017.04.0 02.

Sujarwoto, S., Tampubolon, G., \& Pierewan, A. C. (2018). Individual and contextual factors of happiness and life satisfaction in a low middle income country. Applied Research in Quality of Life, 13(4), 927-945. doi:https://doi.org/10.1007/s11482-0179567-y.

Whillans, A. V., Dunn, E. W., Smeets, P., Bekkers, R., \& Norton, M. I. (2017). Buying time promotes happiness. Proceedings of the National Academy of Sciences, 114(32), 8523-8527. doi:https:// doi.org/10.1073/pnas.1706541114.

Wu, F. (2019). An examination of the effects of consumption expenditures on life satisfaction in Australia. Journal of Happiness Studies, 1-37. doi:https://doi.org/10.1007/s10902-01900161-3.

Xiao, J. J., Ford, M. W., \& Kim, J. (2011). Consumer financial behavior: An interdisciplinary review of selected theories and research. Family and Consumer Sciences Research Journal, 39(4), 399414. doi:https://doi.org/10.1111/j.15523934.2011.02078.x. 